\title{
A PROPOSAL FOR AN INTANGIBLE RESOURCES MANAGEMENT SYSTEM AT THE ORGANIZATIONAL LEVEL
}

\author{
Sebastian, STAN ${ }^{1}$, Camelia, OPREAN-STAN ${ }^{2}$ and Antonio, PELE ${ }^{3}$ \\ ${ }^{1}$ Lucian Blaga University of Sibiu, office.sstan@gmail.com \\ ${ }^{2}$ Lucian Blaga University of Sibiu, camelia.oprean@ulbsibiu.ro \\ ${ }^{3}$ PUC-Rio - Pontifical Catholic University of Rio de Janeiro, antonio.pele.rj@gmail.com
}

\begin{abstract}
The intangible resources management (IRM) is a key area within organizations, not only in terms of theory, but also in practice. However, reality shows that organizations face unexpected challenges in developing and implementing strategies and processes of intangible resources management. This article seeks to contribute to the improvement of IRM at the organization level by building a model that describes the process followed by organizations seeking to implement an intangible resources management system. Our study emphasizes the need of three phases: the identification of critical intangible resources for creating value; the measurement of these resources through a set of indicators and, finally, the monitoring of the resources and intangible activities. However, the management, monitoring and reporting on intangible resources is very idiosyncratic and unique for each organization; there is not a universal recipe, each organization should develop its own process.
\end{abstract}

KEY WORDS: Intangible resources, management, critical resources

\section{INTRODUCTION}

The American economist John Kenneth Galbraith (1) is the one who has focused his attention on the concept of intangibles and intellectual capital, following the observation of significant differences between the market value of a company and its net book value. After some time, efforts have been made to develop intellectual capital research, in almost three directional directions (2). According to Sullivan (3), these efforts were made by Hiroyuki Itarni of Japan (in 1980); David Teece of California (1986); and Karl-Erik Sveiby from Sweden (in 1986). This pioneering work has been continued by many other authors.

Also, in his article published in the Fortune magazine in 1991 (4), Thomas Stewart also used the term intellectual capital. In fact, in the early 1990s, distinctions between the concept of intellectual capital and knowledge management began to emerge, and they were branching out into different disciplines (5). Also in 1991, Skandia, a Swedish insurance company, appointed Leif Edvinsson as the head of intellectual capital, becoming the world's first such manager in an organization. $\mathrm{He}$ was the one who used the metaphor of the tree to describe the hidden value (6), which, in his view, represents the whole of the roots of a tree. The quality of the fruit is based on roots that cannot be seen. Indeed, current accounting fails to reflect the intellectual capital of organizations, just as the roots of a tree are not visible to a person sitting on the ground. But this hidden part can determine and generate success. Moreover, the quality of the root is what determines the performance in the future.

The management of intangible resources (MIR), for the purpose of this paper, refers to the processes and practices used by the organisations to increase their value, by developing the efficiency of creating and exploiting the intangible resources they have.
The greatest challenges faced by organisations regarding the implementation of an MIR system are: identification of both the available intangible resources and the ones required to reach the goals; developing resources (as permanent "flow" to result in the enrichment and superior valorisation of the intangible resource "stock") in order to maintain or increase their capacity to generate a sustainable competitive advantage; the difficulty to measure and evaluate intangible resources; identification of their impact on organisational performance.

Every organisation has as its objective to maintain and increase its intellectual assets, and the intangible resource management is a way to foster this process. Creating and increasing intellectual assets is practically a goal of the organisation, and intangible resource management is a means by which this goal is achieved, this being a process that takes place within the organisation.

In the following lines, we briefly describe the steps to be taken by an organisation that is aware of the importance of intangible resources for the success of its work and is willing to adjust its management control system to explicitly take into account intangible resources. Organisations also need to treat intangible resources management as a strategic issue closely related to the capacity of these resources to create value, and intellectual capital as an essential part of their business processes. When implementing an intangible resource management system, we consider necessary the following three successive phases according to the pattern developed by Sanchez et. al (7) (figure 1): 

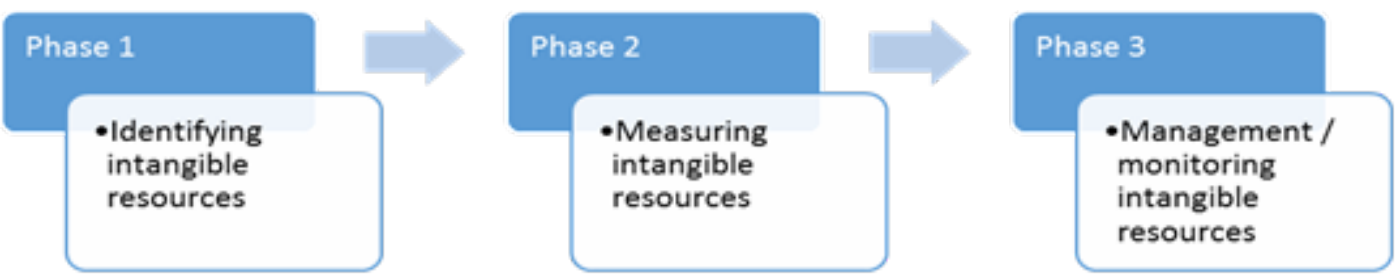

Figure 1. Intangible resource analysis model. Source: after Sanchez et. al (2000)

The identification phase focuses on the so-called critical intangible resources. The organisation must determine what its strategic objectives are and which of the intangible resources are most closely related to them. Then, they need to identify what they need to do in order to create and increase these critical intangible resources, more specifically, the activities positively and negatively affecting intangible resources (dynamic dimension). It is important not to focus only on those activities that could increase the level of critical intangible resources, but also to consider those that may hinder or decrease the level of these resources. In the next step, it is necessary to identify the measures to monitor the level of these intangible resources and the performance of selected intangible activities.

\section{PHASE 1. IDENTIFICATION OF INTANGIBLE RESOURCES}

As mentioned above, at the identification phase of intangible resources, organisations need to focus on those resources which have an impact on the creation of present and future value. This initially involves defining the organisation's view and setting strategic goals by answering some questions, such as those outlined in Figure 2:

\begin{tabular}{|l|l|}
\hline - Where is the organisation placed? \\
\hline $\begin{array}{l}\text { - W it consistent with the (current and future) external } \\
\text { environment? }\end{array}$ \\
\hline
\end{tabular}

Figure 2. Steps in defining strategic goals in order to identify critical intangible resources

A tool to assess the extent to which an organisational resource intangible, in this case - may be the source of the competitive advantage for the firm is the VRIO analytical framework (it is a respective resource: valuable/ rare / inimitable / organisationally valued) - originally developed within the firm's Resource-Based View - Barney (8) which takes into account the following criteria that a resource should satisfy to become a source of sustainable competitive advantage: the value-creating criterion (to be valuable means to be able to exploit opportunities and neutralise threats and it refers to those resources of the organisation that are more efficient and effective than competitors', allowing the firm to enjoy better market performance. With these resources, the organisation may meet the needs of its customers at lower costs, or may exploit opportunities or neutralise threats from competing undertakings); the rareness criterion (a resource must be rare among competitors to be able to help establish a competitive advantage. If a large number of firms in the same industry have that special resource, regardless of whether it is valuable in itself, then the capacity of the holding companies to generate competitive advantage is diminished); the inimitability criterion (inimitable resources are those that cannot be (or it is very difficult to be) imitated, therefore, they are relatively unique to the firm. Its perfect imitation leads to the loss of that resource's capacity to establish a competitive advantage); the non-substitutability criterion (if a resource is very easily substitutable, then its power to contribute to obtaining a competitive advantage decreases). This valuation framework is called the VRIN model - valuable, rare, inimitable, nonsubstitutable.

Later, Barney introduces the VRIO valuation framework, which is an improvement of the VRIN model. The VRIO analysis is based on the answer to four (tangible and intangible) resource-related questions: is the resource valuable?; Is it rare?; Is it expensive to imitate it?; Is it valued at the organisational level (a firm should be able to organise its management systems, processes, policies, organisational structure etc. in order to be able to fully capture the potential of its resources)? A resource that meets all four requirements can bring a sustained competitive advantage to the organisation. There is an example below on the application of the VRIO model and the probable outcome for the organisation in different circumstances (see Tables 1, 2, 3). 
Table 1. Applying the VRIO model - value and rarity of the organisation's resources

\begin{tabular}{c|c|c}
\hline If the resources are: & & The organisation may expect: \\
\hline Not valuable & $\longrightarrow$ & Competitive disadvantage \\
\hline Valuable, but not rare & $\longrightarrow$ & Competitive equality \\
\hline Valuable and rare & $\longrightarrow$ & Competitive advantage (at least temporarily) \\
\hline
\end{tabular}

Then, if there are high costs to imitate the resources, the firm may enjoy a period of sustained competitive advantage.

Table 2. Applying the VRIO model, integrating resource inimitable feature

\begin{tabular}{|c|c|c|}
\hline If the resources are: & & The organisation may expect: \\
\hline Valuable, rare, but not costly to imitate & $\longrightarrow$ & Temporary competitive advantage \\
\hline Valuable, rare, and costly to imitate & $\longrightarrow$ & $\begin{array}{c}\text { Sustained competitive advantage } \\
\text { (if organised properly) }\end{array}$ \\
\hline
\end{tabular}

Competitive advantage properly organised refers to elements such as firm's structure and control (management mechanisms - compensation, reporting structures, management control, relationships etc.).

Table 3. Summary of VRIO analysis, competitive and economic implications

\begin{tabular}{|c|c|c|c|c|c|}
\hline \multicolumn{4}{|c|}{ Resource X } & \multicolumn{2}{|r|}{ Implications } \\
\hline Valuable? & Rare? & $\begin{array}{l}\text { Costly to } \\
\text { Imitate? }\end{array}$ & $\begin{array}{l}\text { Organisationally } \\
\text { Valued? }\end{array}$ & Competitive & Economic \\
\hline No & & & No 4 & Disadvantage & Performance below average \\
\hline Yes & No & & & Equality & Average performance \\
\hline Yes & Yes & No & & $\begin{array}{l}\text { Temporary } \\
\text { advantage }\end{array}$ & $\begin{array}{c}\text { Performance above average } \\
\text { (at least temporarily) }\end{array}$ \\
\hline Yes & Yes & Yes & Yes & $\begin{array}{l}\text { Sustained } \\
\text { advantage }\end{array}$ & Performance above average \\
\hline
\end{tabular}

For each intangible resource, there may be four situations, represented in Figure 3:

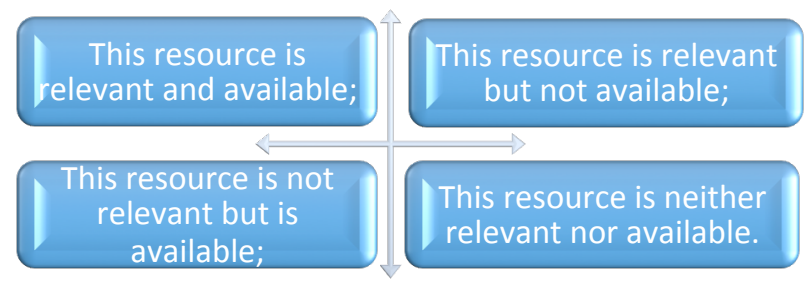

Figure 3. Cases in which intangible resources can be found after valuation, depending on relevance and availability (9)

As a result of this in-depth analysis to identify resources closely related to the organisation's strategic goals, a critical intangible resource network will be generated representing the key factors most involved in creating and increasing value in
These four features of the abovementioned resources must be aligned so as to give managers the ability to exploit them at the organisation level (see Table 3). 


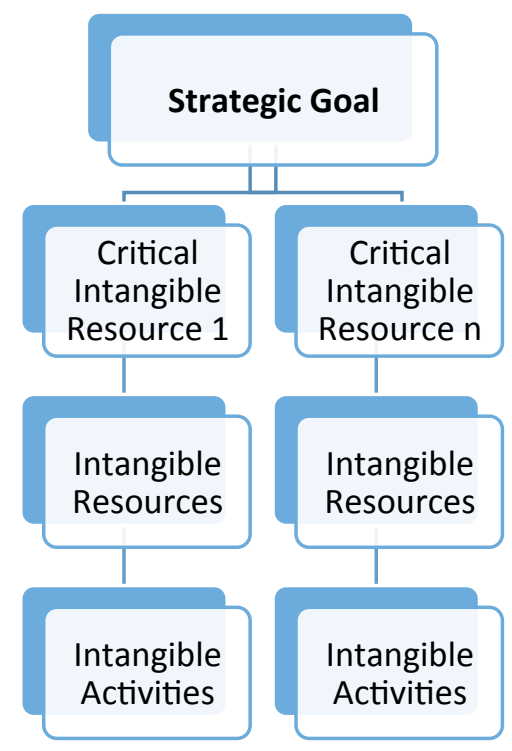

Figure 4. The pyramid of critical intangible resources depending on a strategic goal. Source: Sanchez et al., 2000

At the top of the pyramid we shall find a set of critical intangible resources helping maintain or enhance the competitive advantage of an organisation or reach strategic goals. A number of activities and resources could affect every critical intangible resource. In most cases, the organisation is not sure about the exact impact of each activity on the resource, but based on its past experience, it can judge whether it affects or not the critical intangible resource. This is enough to consider it as an intangible activity, or, in other words, as an intangible investment. In order to better assess the causality between actions and outcomes, a final set of activities needs to be developed. Assessing results is critical since it defines the organisation's ability to learn from its actions and to continuously improve its work.

There may be cases where not all intangible resources have the same relative importance regarding management and monitoring. Some of them may be considered essential and deserve special attention while others may be considered less important but they still need to be managed and accounted for.

\section{PHASE 2. MEASUREMENT OF INTANGIBLE RESOURCES}

Once the causal relationship network has been identified and established for the critical intangible resources, the organisation has to define specific indicators serving to evaluate each intangible item. For example, if the resource is relevant and available, the organisation should start identifying an appropriate set of indicators, focusing on how the resource has been generated, how it is currently used, and what benefits it provides, but also how its substitution or regeneration is managed (the planning stage). If the resource is relevant but it is not available, an appropriate set of indicators should be identified, able to demonstrate the organisation's efforts to obtain it. Therefore, only the planning section should be used. If the resource is not relevant but it is available, the indicators needed to estimate the value likely to be obtained by outsourcing (to other entities - the transferability section) should be used. Finally, if the resource is neither relevant nor available, then no indicator is required.

Indicators may be financial (monetary) or non-financial, as they are used to measure both intangible resources and intangible activities. It is clear that intangible activities are always costly for the organisation, but this one is not always able to estimate the cost of these activities, or in some cases certain activities are considered strategic, so that their cost is no longer relevant. It is clear that for the management process, indicators of the impact of intangible resources and intangible activities on the financial variables would also be desirable. It is however important for the indicators to provide a clear idea, where possible, on the connection between the company's intangible resources and activities and the wealth newly created by these intangible elements.

The valuation of intangible resources remains one of the most complex problems to solve that is why in the second chapter of this work we will deal with the presentation of the most important valuation models established in the literature. At the heart of the problem is the fact that these intangible resources can only be valued when they are sold. However, without knowing their value, it becomes difficult to establish the sales price. Each organisation confers a different value on intangible resources and intellectual capital. What is important for an organisation may not be important for another, thus making it difficult to develop a universal valuation model.

\section{PHASE 3. MONITORING INTANGIBLE RESOURCES}

Once the measurement system is developed and implemented, organisations should analyse the outcomes internally obtained. This task is usually attributed to top managers. Regarding the monitoring of intangible resources, it is important to bear in mind that organisations do not always intend to maximize the indicators proposed for the measurement of intangible resources. The goal set for certain resources may be to reach an optimal level, while for others an increase or decrease might be desirable.

The monitoring phase refers to strengthening the intangible resource management system and integrating it as efficiently as possible in the organisation's routine. At this stage, both the organisation's intellectual capital stock and the effect of various activities on intangible resources are evaluated. As a result, strengths and weaknesses should be identified and needs for further intangible activities shall emerge.

In conclusion, the monitoring phase is part of a highly dynamic process in which the valuation of the outcomes and the possible design of new activities may occasionally overlap with the 
identification and measurement phases. It is the climax of implementing an intangible resource management system within the organisation. The more the monitoring phase is integrated into the organisational routines, the more the intangible management process becomes more consolidated and therefore the higher the recognition will be at the external and internal levels.

\section{CONCLUSIONS}

Generating and enhancing intellectual capital is practically an organisational goal, whilst intangible resources management is the means by which this goal is achieved, being a process taking place within the organisation. Intangible resource management is a concept much wider than knowledge management. Its main purpose is to increase the value of the firm by creating competitive advantages. The management of intangible resources involves identifying these resources, assessing their impact on the present and future value of the firm, their assessment, the discovery of intangible activities, and ultimately the ability to effectively manage these activities. Creating knowledge is an intangible resource that organisations need to manage just as they manage other resources of this nature, so knowledge management is a subset of intangible resource management.

Despite its importance, organisations are faced with a number of difficulties in implementing intangible resource management, especially in identifying, assessing and monitoring intangible resources.

\section{REFERENCES}

1. Galbraith J. K. (1969). The New Industrial State, Harmondsworth: Penguin

2. McGill T. P. (2006), Harnessing Intellectual Capital: A Study of Organizational Knowledge, UMI Dissertation Publishing, Number: 3235051, ProQuest LLC

3. Sullivan P. H. (2000), Value-driven intellectual capital; How to convert intangible corporate assets into market value. New York: John Wiley \& Sons

4. Stewart T. A. (2001), Intellectual capital: Ten years later, how far we've come [Electronic version]. Fortune, 143, pg. 192-193

5. Anderson K. K. (2009), Organizational Capabilities as Predictors of Effective Knowledge Management: an Empirical Examination, UMI Dissertation Publishing, Number: 3369510, ProQuest LLC

6. Suciu M. C. (2008), Activele intangibile și capitalul intelectual - factori cheie ai convergenței, Seria Working Papers nr. 7, Academia Romană, Institutul Naţional de Cercetări Economice

7. Sanchez M. P., Chaminade C., Olea M., 2000. Management of intangibles: an attempt to build a theory, Journal of Intellectual Capital, 1(4), 312-327 p., http://dx.doi.org/10.1108/14691930010359225

8. Barney J. B., 1991. Firm Resources and Sustained Competitive Advantage, Journal of Management, 17(1), http://dx.doi.org/10.1177/014920639101700108

9. EVLIA project - Making full value of good ideas by leveraging intellectual assets for financing SME's in SEE, http://www.evlia.eu 